\title{
DOCUMENTATION OF MODEL INPUT AND OUTPUT VALUES FOR THE GEOHYDROLOGY AND GROUND-WATER-FLOW SIMULATION OF THE SURPRISE SPRING BASIN AQUIFER SYSTEM, SAN BERNARDINO COUNTY, CALIFORNIA
}

By Hugh T. Mitten and Clark J. Londquist

Supplement to Water-Resources Investigations Report 89-4099

U.S. GEOLOGICAL SURVEY

Open-File Report 91-482 


\section{U.S. DEPARTMENT OF THE INTERIOR MANUEL LUJAN, JR., Secretary}

U.S. GEOLOGICAL SURVEY

Dallas L. Peck, Director

The use of brand, firm, or trade names and the use and distribution of specific products in this report are for identification purposes only and do not imply endorsement by the U.S. Geological Survey. No warranty is made for the use of the products.

For sale by the Books and Open-File Reports Section U.S. Geological Survey

Federal Center, Box 25425

Denver, CO 80225

For additional information write to:

District Chief

U.S. Geological Survey

Federal Building, Room W-2234

2800 Cottage Way

Sacramento, CA 95825 


\title{
CONTENTS
}

\author{
Abstract 1 \\ Introduction 1 \\ Model documentation 2 \\ Model grid 2 \\ Input and output files 2
}

Compression-decompression program $\mathbf{2}$

Menu method 5

DOS method 5

Selected references $\mathbf{5}$

\section{ILLUSTRATION}

Figure 1. Chart showing menus to select drive and files 5

\section{TABLES}

Table 1. Contents of root directory 2

2. Model-input files, Fortran units, maximum record length, number of records, size, and descriptions $\mathbf{3}$

3. Model-output files assigned to Fortran unit 6, number of records, size, and descriptions 4 


\title{
DOCUMENTATION OF MODEL INPUT AND OUTPUT VALUES FOR THE GEOHYDROLOGY AND GROUND-WATER-FLOW SIMULATION OF
}

\author{
THE SURPRISE SPRING BASIN AQUIFER SYSTEM,
}

SAN BERNARDINO COUNTY, CALIFORNIA

\author{
By Hugh T. Mitten and Clark J. Londquist
}

\begin{abstract}
Model input and sample output values for the geohydrology and ground-water-flow simulation of the Surprise Spring basin aquifer system, San Bernardino County, Califormia, were not documented in the original report. In this report, the documentation is contained on a 1.2 megabyte, 5 1/4-inch diskette in self-expanding compressed files, which can be decompressed with easy-to-use menus. The decompressed input and output files are presented according to the American International Standard Code for Information Interchange and require approximately 4.1 megabytes of disk space on an IBM-compatible microcomputer using the MS-DOS operating system.
\end{abstract}

\section{INTRODUCTION}

As part of a study of the geohydrology and ground-water flow of the Surprise Spring basin aquifer system, San Bernardino County, California, Londquist and Martin (1991) developed a two-layer mathematical model using the computational algorithm of McDonald and Harbaugh (1988). Although model input is summarized by Londquist and Martin (1991), detailed documentation of the grid location, model input, and sample output is not included. This report, a supplement to the report by Londquist and Martin (1991), provides detailed documentation of the model.

The original input and output for the Surprise Spring model were developed on a Prime computer, transferred to a microcomputer, and compressed so they could be placed on a single diskette. Those compressed files were collected into self-extracting files called libraries. The contents of each library can be extracted by typing the library name and pressing the enter key, thus decompressing the files into the original form according to the American International Stañdard Code for Information Interchange (ASCII).

This report is in two parts. The first part consists of this introductory text, a listing of input and output files, and an explanation of the decompression program. The compression-decompression program, LHarc, is copyrighted by Haruyasu Yoshizaki. Permission to copy is granted freely, provided that all copies contain the statement, "Copyright by Haruyasu Yoshizaki."

The second part of the report is a diskette that includes a copy of this text, the compressed files, and one subdirectory. The diskette is available for purchase from the U.S. Geological Survey Books and Open-File Reports Section at the address shown on the back of the title page. The high-density, doublesided, soft-sectored diskette has a capacity of 1.2 megabytes. Files on the diskette were created on an IBM compatible microcomputer using MS-DOS version 3.3. The compressed files for the model reside in two of the libraries: INPUT.EXE and OUTPUT.EXE. Table 1 shows contents of the root directory and a description of its contents. 
Table 1. Contents of root directory

\begin{tabular}{|c|c|}
\hline Item & Description \\
\hline README.DOC & This report. An ASCII file. \\
\hline SURPRISE.BAT & Batch file for menu method of decompressing files. An ASCII file. \\
\hline INPUT.EXE & The self-extracting compressed library of model-input files (table 2). A non-ASCII file. \\
\hline OUTPUT.EXE & The self-extracting compressed library of model-output files (table 3). A non-ASCII file. \\
\hline LH113C.EXE & $\begin{array}{l}\text { The self-extracting library of file-compression/decompression programs including documentation. } \\
\text { The "Compression-Decompression Program" section of this report explains how to decompress } \\
\text { this library. A non-ASCII file. }\end{array}$ \\
\hline UTIL & Subdirectory containing menu-driven utilities. \\
\hline
\end{tabular}

MODEL DOCUMENTATION

\section{MODEL GRID}

Organization of the finite-difference model grid was based on a mosaic of $1: 62,500$ scale topographic maps. The origin of the model grid (the westernmost comer of row 1 , column 1) is 1,250 feet north and 2,900 feet west of the southeast comer of section 32, township 4 north, range 6 east. The locations of the other three comers of the grid are 950 feet south and 1,200 feet east of the northwest comer of section 20 , township 4 north, range 7 east; 500 feet south and 2,200 feet east of the northwest corner of section 32 , township 2 north, range 8 east; and 1,650 feet north and 1,800 feet west of the southeast corner of section 8 , township 1 north, range 7 east. All locations refer to the San Bernardino base line and meridian of the public land-survey system for California.

\section{INPUT AND OUTPUT FILES}

Decompression of the compressed libraries, INPUT.EXE and OUTPUT.EXE (table 1), creates 37 model-input files (table 2), and 5 model-output files (table 3). Units for the input and output files are in combinations of feet and seconds, where applicable. A total of about 4.1 megabytes is required on the hard disk to hold all the decompressed input and output
ASCII files. The input files contain records of varying lengths (table 2); the records in output files are 132 characters or less.

The model simulates five pumping conditions: steady state, calibrated transient state, and three predictive transient states. The model program, written in Fortran 77 , can be run on a variety of computers. However, the user might need to reorganize the input data, depending on the specific computer and compiler being used, and the computed output might differ slightly from that presented here.

\section{COMPRESSION-DECOMPRESSION PROGRAM}

LHarc is the program used to compress the original model input and output files into self-extracting libraries. The LHarc program and documentation may be obtained by copying LH113C.EXE to any directory on either the hard disk or a diskette, typing 'LH113C', and pressing the enter key. There is enough room on the Surprise Spring diskette for the program and documentation, which require 109,534 bytes.

There are two methods to decompress the INPUT.EXE and OUTPUT.EXE files. The "menu method" requires a version of MS-DOS more recent than 2.0, and the "DOS method" is used for versions 2.0 or earlier. 
Table 2. Model-input files, Fortran units, maximum record length, number of records, size, and descriptions

[The suffix PAC refers to a package or module of the computational algorithm, DAT to data, and CON to control. Asterisk $(*)$ indicates record length is 80 characters or less]

\begin{tabular}{|c|c|c|c|c|c|}
\hline File & $\begin{array}{c}\text { Fortran } \\
\text { unit }\end{array}$ & $\begin{array}{l}\text { Maximum } \\
\text { record } \\
\text { length }\end{array}$ & $\begin{array}{l}\text { Number } \\
\text { of } \\
\text { records }\end{array}$ & $\begin{array}{c}\text { Size } \\
\text { (bytes) }\end{array}$ & Description \\
\hline BASICPD.PAC & 5 & * & 76 & 6,003 & Basic package, predictive transient-state simulations. \\
\hline BASICSS.PAC & 5 & * & 43 & 3,399 & Basic package, steady-state simulations. \\
\hline BASICTR.PAC & 5 & * & 43 & 3,396 & Basic package, calibrated transient-state simulations. \\
\hline BCFSS.PAC & 20 & $*$ & 11 & 869 & Block-centered-flow package, steady-state simulations. \\
\hline BCFTRPD.PAC & 20 & $*$ & 14 & 1,105 & $\begin{array}{l}\text { Block-centered-flow package, all transient-state } \\
\text { simulations. }\end{array}$ \\
\hline ETRATETR.DAT & 111 & 110 & 138 & 15,456 & $\begin{array}{l}\text { Evapotranspiration rate, calibrated transient-state } \\
\text { simulations. }\end{array}$ \\
\hline ETSTOPTR.DAT & 112 & 110 & 138 & 15,456 & $\begin{array}{l}\text { Evapotranspiration depth, calibrated transient-state } \\
\text { simulations. }\end{array}$ \\
\hline ETSURFTR.DAT & 110 & 110 & 138 & 15,456 & $\begin{array}{l}\text { Evapotranspiration, land-surface altitude, calibrated } \\
\text { transient-state simulations. }\end{array}$ \\
\hline ETTR.PAC & 109 & * & 95 & 3,090 & $\begin{array}{l}\text { Evapotranspiration package, calibrated transient-state } \\
\text { simulations. }\end{array}$ \\
\hline GHB.PAC & 19 & * & 156 & 2,922 & General-head-boundary package. \\
\hline GRID.DAT & 11 & 88 & 3 & 232 & Grid spacing. \\
\hline L1BOTALT.DAT & 13 & * & 207 & 15,594 & Layer 1 bottom altitude. \\
\hline L1BOUND.DAT & 7 & 88 & 69 & 6,210 & Layer 1 boundary. \\
\hline LICON.DAT & 12 & 100 & 345 & 31,050 & Layer 1 lateral hydraulic conductivity. \\
\hline L1HDSPD.DAT & 9 & * & 345 & 24,978 & Layer 1 heads, predictive transient-state simulations. \\
\hline L1HDSSS.DAT & 9 & * & 345 & 24,978 & Layer 1 heads, steady-state simulations. \\
\hline L1HDSTR.DAT & 9 & * & 345 & 24,978 & Layer 1 heads, calibrated transient-state simulations. \\
\hline L1SF1.DAT & 32 & 100 & 345 & 31,050 & Layer 1 primary storage (specific yield). \\
\hline L2BOTALT.DAT & 34 & $*$ & 207 & 15,594 & Layer 2 bottom altitude. \\
\hline L2BOUND.DAT & 8 & 88 & 69 & 6,210 & Layer 2 boundary. \\
\hline L2CON.DAT & 15 & 100 & 345 & 31,050 & Layer 2 lateral hydraulic conductivity. \\
\hline L2HDSPD.DAT & 10 & $*$ & 345 & 24,978 & Layer 2 heads, predictive transient-state simulations. \\
\hline L2HDSSS.DAT & 10 & * & 345 & 24,978 & Layer 2 heads, steady-state simulations. \\
\hline L2HDSTR.DAT & 10 & * & 345 & 24,978 & Layer 2 heads, calibrated transient-state simulations. \\
\hline L2SF1.DAT & 33 & 100 & 345 & 31,050 & Layer 2 primary storage (confined storage coefficient). \\
\hline
\end{tabular}


Table 2. Model-input files, Fortran units, maximum record length, number of records, size, and descriptions--Continued

\begin{tabular}{|c|c|c|c|c|c|}
\hline File & $\begin{array}{l}\text { Fortran } \\
\text { unit }\end{array}$ & $\begin{array}{l}\text { Maximum } \\
\text { record } \\
\text { length }\end{array}$ & $\begin{array}{l}\text { Number } \\
\text { of } \\
\text { records }\end{array}$ & $\begin{array}{c}\text { Size } \\
\text { (bytes) }\end{array}$ & Description \\
\hline L2SF2.DAT & 35 & 100 & 345 & 31,050 & Layer 2 secondary storage (specific yield). \\
\hline L2TOPALT.DAT & 36 & * & 207 & 15,594 & Layer 2 top altitude. \\
\hline OUTPUTPD.CON & 30 & * & 451 & 35,592 & Output control, predictive transient-state simulations. \\
\hline OUTPUTSS.CON & 30 & * & 10 & 753 & Output control, steady-state simulation. \\
\hline OUTPUTTR.CON & 30 & * & 298 & 23,505 & Output control, calibrated transient-state simulations. \\
\hline SSOR.PAC & 29 & * & 2 & 158 & Slice-successive-overrelaxation package. \\
\hline VCONT.DAT & 14 & 120 & 345 & 36,502 & $\begin{array}{l}\text { Variable including vertical hydraulic conductivity and } \\
\text { thickness of layers. }\end{array}$ \\
\hline WELCONPD.PAC & 31 & * & 119 & 2,570 & $\begin{array}{l}\text { Well package, predictive } 50 \text {-year transient-state } \\
\text { simulation using } 1985 \text { pumpage. }\end{array}$ \\
\hline WELNEWPD.PAC & 31 & $*$ & 327 & 11,899 & $\begin{array}{l}\text { Well package, predictive } 50 \text {-year transient-state } \\
\text { simulation using } 1985 \text { pumpage plus projected } \\
\text { pumpage from } 3 \text { wells. }\end{array}$ \\
\hline WELOLDPD.PAC & 31 & * & 309 & 10,400 & $\begin{array}{l}\text { Well package, predictive } 50 \text {-year transient-state } \\
\text { simulation using projected pumpage added to } 1985 \\
\text { pumpage at } 1985 \text { well locations. }\end{array}$ \\
\hline WELSS.PAC & 31 & $*$ & 32 & 1,294 & Well package, steady-state simulation. \\
\hline WELTR.PAC & 31 & $*$ & 1140 & 46,870 & Well package, calibrated transient-state simulation. \\
\hline TOTAL & & & & 601,247 & \\
\hline
\end{tabular}

Table 3. Model-output files assigned to Fortran unit 6, number of records, size, and descriptions

\begin{tabular}{|c|c|c|c|}
\hline File & $\begin{array}{l}\text { Number } \\
\text { of records }\end{array}$ & $\begin{array}{c}\text { Size } \\
\text { (bytes) }\end{array}$ & Description \\
\hline STEADY.OUT & 3,524 & 421,025 & Steady-state simulation. \\
\hline PREDCON.OUT & 7,805 & 718,416 & Predictive 50-year transient-state simulation using 1985 pumpage. \\
\hline PREDNEW.OUT & 8,066 & 743,561 & $\begin{array}{l}\text { Predictive 50-year transient-state simulation using } 1985 \text { pumpage } \\
\text { plus projected pumpage from } 3 \text { wells. }\end{array}$ \\
\hline PREDOLD.OUT & 8,139 & 751,358 & $\begin{array}{l}\text { Predictive } 50 \text {-year transient-state simulation using projected } \\
\text { pumpage added to } 1985 \text { pumpage at } 1985 \text { well locations. }\end{array}$ \\
\hline TRANS.OUT & 8,315 & 816,053 & Calibrated transient-state simulation. \\
\hline TOTAL & & $\overline{3,450,413}$ & \\
\hline
\end{tabular}




\section{MENU METHOD}

To implement the decompression program, place the diskette in drive $A:$, attach to A:, type 'SURPRISE', and press the enter key. The menu shown in figure $1 A$ will appear. When either drive $C$ : or $\mathrm{D}$ : is selected, the menu shown in figure $1 B$ will appear. By selecting choices from both menus, each group of files may be placed on either or both drives in any convenient combination.

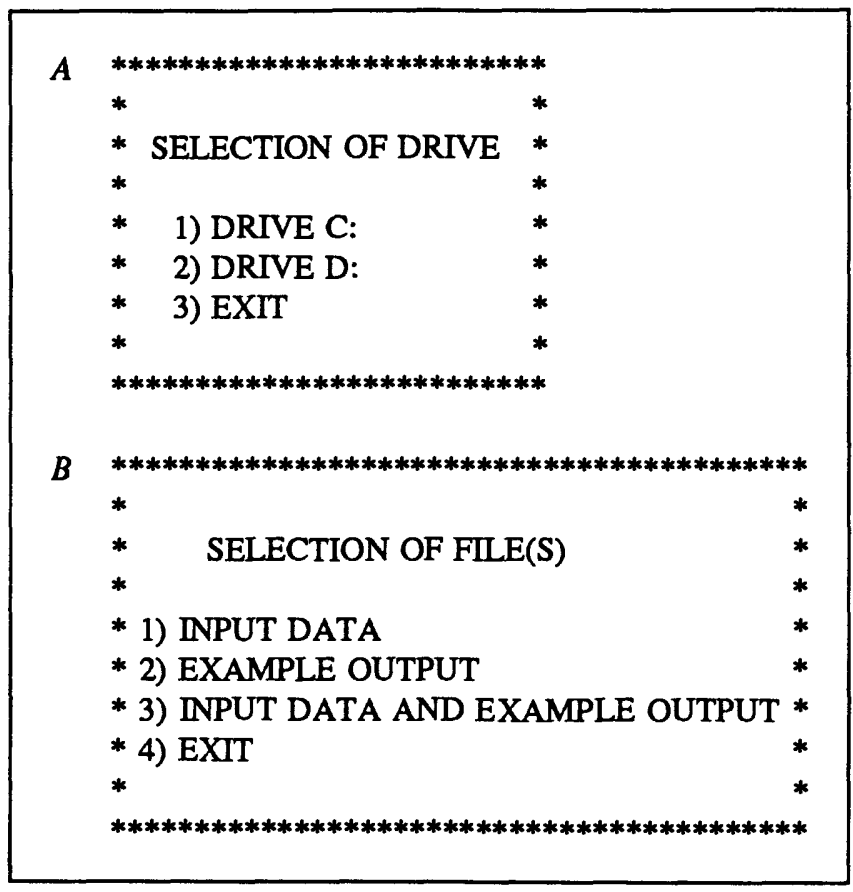

Figure 1. Menus to select drive and files.
Decompressing the self-extracting files will create a SURPRISE directory on the drive(s) and, depending on the option selected, subdirectories INPUT and OUTPUT. These subdirectories will contain the decompressed input and output files totaling 618,432 and $3,450,443$ bytes of disk space respectively.

\section{DOS METHOD}

Files can be decompressed and placed in any drive having sufficient free space by copying the appropriate filename.EXE to a subdirectory of that drive and then executing by typing the file name. For example, if the input files are to be placed in a subdirectory named MODEL on the D: drive, copy the file INPUT.EXE to D:MODEL; attach to that directory; type 'INPUT'; and press the enter key. Computer instructions contained within INPUT.EXE will cause the decompression of this file and place decompressed files into D:MODEL.

\section{SELECTED REFERENCES}

Londquist, C.J., and Martin, Peter, 1991, Geohydrology and ground-water-flow simulation of the Surprise Spring basin aquifer system, San Bernardino County, California: U.S. Geological Survey Water-Resources Investigations Report 89-4099, 41 p.

McDonald, M.G., and Harbaugh, A.W., 1988, A modular three-dimensional finite-difference ground-water flow model: U.S. Geological Survey Techniques of WaterResources Investigations, book 6, chap. A1, 576 p.

Wolverton, Van, 1986, Supercharging MS-DOS: Redmond, Washington, Microsoft Press, 300 p. 